\title{
Assessment of Probiotic Attributes of Food Grade Lactic Acid Bacteria Isolated from a Novel Traditional Fermented Product- Luske of Northern Himalayas
}

\author{
Ranjana Sharma* and Nivedita Sharma
}

\author{
Microbiology Research Laboratory, Department of Basic Sciences, Dr Y S Parmar University of \\ Horticulture and Forestry, Nauni, Solan (India)-173230, HP, India \\ *Corresponding author
}

A B S T R A C T

Keywords

Antagonism,

Functional food,

Lactic acid

bacteria,

Probiotics,

Traditional

fermented foods.

Article Info

Accepted:

26 June 2017

Available Online:

10 July 2017
The aim of the present study was to access probiotic attributes such as antimicrobial activity, acid and bile tolerance, auto aggregation capacity, hydrophobicity assay and antibiotic susceptibility of two screened potential lactic acid bacterial strains from a novel traditional fermented product (viz. Luske, prepared using fermented lassi) Solan District of Himachal Pradesh. Six isolates were isolated from the traditional fermented foods of a Trans Himalayan state of India and were subjected to biochemical characterization. Preliminary screening demonstrated variable inhibitory activity against various food borne pathogens and among them L1 and L2 were found to have broad spectrum antagonism. The genomic level identification had been performed and screened cultures of lactic acid bacteria from luske was identified as Pediococcus acidilactici L1 with accession number |KM251713| and Lactobacillus plantarum L2 with accession number |KM251714|. The results showed that the isolates were able to tolerate acidity upto $90 \mathrm{~min}$ as low $\mathrm{pH}$ as 2 and bile salt of $2 \%$. The percentage of auto aggregation and hydrophobicity of the strains ranged from $48.4 \%$ and $90 \%$. As the two isolates were sensitive to most of the tested antibiotics, these data suggest that such isolates can be considered potential candidates for probiotic use in functional food formulations.

\section{Introduction}

Probiotics are beneficial bacteria. These are defined as "live microorganisms which when administered in adequate amounts confer a health benefit on the host" (FAO/WHO, 2006). Probiotics have great potential in medicine, prevention and treatment of gastrointestinal infections, inflammations and allergic reactions (Shigwedha et al., 2014). Among probiotics, the most preferred group of bacteria lactic acid bacteria (LAB) are Gram-positive, low-GC, acid-tolerant, generally non-sporulating, non-motile, nonrespiring, rod or cocci. Within the group of
LAB, Lactobacillus species are most commonly utilized group (Pundir et al., 2013). The traditional fermented foods and beverages form important constituents of staple diet of the people belonging to India. In India, the northern hilly state of Himachal Pradesh is well known for its ethnic food. A wide range of traditional fermented products are prepared and consumed in Himachal Pradesh. Mostly these fermented foods are either cereal-based (wheat/barley/buckwheat/ ragi), milk-based or beverages. Some of the products like Bhaturu, Siddu, Luske, Chilra, 
Marchu, Manna, Dosha, Pinni/Bagpinni, Seera, chaang and angoori etc. are unique to Himachal Pradesh representing rich repositories of potential probiotics. These traditional fermented food items are least explored, rich niches of rare/novel probiotic strains and have great potential health beneficiaries of yielding highly desirable probiotic microorganism upon isolation.

Thus, probiotics play highly useful and important role in maintaining our system healthy.

Nowadays, the commercially claimed probiotics have been proven ineffective and sometimes false due to many reasons like-less number of cells per unit of product, lack of colonization, less bioavailability, etc. So, there is a high demand to isolate and explore the good potential probiotic strains from different potential sources viz. fermented food for their successful commercialization.

\section{Materials and Methods}

\section{Isolation of probiotic potential bacteria}

Three different samples viz. chur saag, siddu and luske were collected from Northern hilly state of India (Himachal Pradesh). From each of these samples, stock and all samples were serially diluted by serial dilution in the dilution range of $10^{-2}$ to $10^{-12}$. The samples of $0.1 \mathrm{ml}$ each were mounted by spread plate method on sterilized petriplates containing solidified de Man, Rogosa, Sharpe (MRS) agar. Plates were kept in anaerobic jar and incubated at $37^{\circ} \mathrm{C}$ for $48 \mathrm{~h}$.

\section{Physiology and biochemical characterization}

Tentative identification of the isolates was carried out using morphological and biochemical methods. The identification of the isolates was performed according to the criteria of Bergey's Manual of Determinative Bacteriology ( $7^{\text {th }} \mathrm{Edn}$.).

\section{Preliminary screening of isolated bacterial strains}

Different bacterial and fungal indicators viz., Staphylococcus aureus IGMC, Enterococcus faecalis MTCC 2729, Listeria monocytogens MTCC 839, Clostridium perfringens MTCC 1739, Bacillus cereus, Rhizoctonia solani, Aspergillus niger, Rhizopus sp. and Fusarium sp. were used to check antagonistic activity of the isolates. The bit of isolated bacterial strains was kept on lawn of indicator microorganisms. The diameter of zone formed was measured as its zone size.

\section{Genotypic identification}

The sequence analysis of 16S rRNA gene was employed for identification of isolate L1 and L2. Genomic DNA of selected isolates was isolated by the protocol with some amendments (Rodriguez and Tait , 1983). $1.5 \mathrm{~Kb}$ long fragment of the $16 \mathrm{~S}$ rRNA gene was amplified from the extracted DNA using eubacterial universal primers [Forward primers: 5' AGAGTTTGATCMTGGCTCA G3') and Reverse primers: (5' ACCTTGTTA CGACTT3')] specific for $16 \mathrm{~S}$ rRNA gene. The partial genome sequence of approximately $700 \mathrm{bp}$ long $16 \mathrm{~S}$ rRNA gene was obtained and sequence homologies were analyzed by comparative studies using "The National Center for Biotechnology Information (NCBI)" using web link (http://www. Ncbi.nlm.nih.gov/) and Basic Alignment Search Tool (BLAST).

The sequences were then aligned with two closest sequences via Clustal V Multiple Sequences Alignment using web links (http://www.ebi.ac.uk/Tools/msa/clustalw2/). The sequences were then submitted to GenBank databases. 


\section{Probiotic attributes}

\section{pH tolerance}

Tolerance to different $\mathrm{pH}$ was evaluated according to Gotcheva et al., (2002) and the percent survival was calculated according to the formula as follows:

$\%$ Survivability $=\left(\log \mathrm{cfu} 30^{\text {th }} \min / \log \mathrm{cfu}\right.$ $\left.0^{\text {th }} \min \right) \times 100$

\section{Bile tolerance}

Tolerance to bile salt was performed according to Dora and Glenn (2002). Each selected bacterial culture was inoculated in the MRS medium containing varying concentrations of bile salt $(0.3,1.0$ and $2.0 \%)$ and incubated at $37^{\circ} \mathrm{C}$ for $72 \mathrm{~h}$. The optical density (OD) was measured at $620 \mathrm{~nm}$ and compared to control culture without bile salt.

\section{Antibiotic susceptibility}

The antibiotic susceptibility of selected bacterial strains was assessed using antibiotic discs (HiMedia ${ }^{\circledR}$ ) by diffusion method on solid MRS medium agar plates. The results were expressed as sensitivity (S) or resistant (R).

\section{Auto aggregation assays}

Auto aggregation assays were performed (Kos et al., 2003) and the absorbance was measured at $600 \mathrm{~nm}$.

\section{Cell hydrophobicity assay}

Determination of cell surface hydrophobicity was evaluated and results were expressed as described by Mishra and Prasad (2005). The percent hydrophobicity was calculated from the formula as given below:

Hydrophobicity $\%=\left[\left(\mathrm{A}_{0}-\mathrm{A}\right) / \mathrm{A}_{0}\right] \times 100$

\section{Inter compatibility testing}

Compatibility of these two bacterial isolates with each other was checked by using Cross streak method on MRS plates at $37^{\circ} \mathrm{C}$ for $24 \mathrm{~h}$ (Barefoot and Klanhammer, 1983).

\section{Cumulative probiotic score}

The cumulative probiotic potential of selected bacterial isolates was calculated using standard score card described by Tambekar and Bhutada (2010) and formula as follows:

$$
\begin{gathered}
\text { Probiotic } \\
\text { potential }
\end{gathered}=\frac{\begin{array}{c}
\text { Observed } \\
\text { score }
\end{array}}{\substack{\text { Maximum } \\
\text { score }}} \times 100
$$

\section{Results and Discussion}

The morphology of isolates was given in Plate 1 and biochemical characters are noted down. Both isolates were found to be rod shaped, gram positive, catalase negative, able to ferment carbohydrates but not gas, indole negative, MRVP positive, $\mathrm{H}_{2} \mathrm{~S}$ production and facultative anaerobes whereas, L1 was urease positive and L2 was not able to hydrolyze casein. The data on inhibitory spectrum of lactic acid bacteria by bit/disc method against test strains i.e. food borne pathogens and spoilage causing microorganism, had been shown in table 1 .

A total of six strains were isolated out of the three food sources used and out of these six strains isolated only two (i.e. L1 and L2) were selected for further studies based upon their strongest and broadest antagonistic spectrum against the tested pathogenic bacterial and fungal strains. L1 and L2 both were isolated from luske. The genomic identification showed L1 was Pediococcus acidilactici and L2 was Lactobacillus plantarum. The strains designation and GenBank accession number for the sequence derived from 16S rRNA 
gene analysis are shown in table 2 and their phylogenetic tree were shown in figures 1 and 2. Similar study, where LAB from dried fruits were isolated and identified as Lactococcus sp., Streptococcus thermophiles, Pediococcus acidilactici and Lactobacillus sp. (Askari et al., 2012).

When tested for low $\mathrm{pH}$ survival, both of these isolates showed quite high level of acidity tolerance ranging from $54.9-69.2 \%$ at $\mathrm{pH} 2-3$ after $90 \mathrm{~min}$ of incubation (Table 3). This trait of isolates is a highly desirable probiotic criterion to survive in acidic gastric environment.

Survival of only one isolate at $\mathrm{pH} 3.0$ out of eighteen different Lactobacillus strains isolated from Moroccan traditional dairy products (Jamaly et al., 2011).

Furthermore, the results obtained for bile salt tolerance expressed that both the two lactic acid bacterial strains were able to tolerate as high bile salt concentration as $2 \%$ and exhibiting survival rate in between 63.88 to $80.48 \%$ as depicted in figure 3 rendering these isolates as potential candidates for their use as probiotics. The isolates demonstrated good capacity to resist bile salts by presenting surviving percentage greater than $50 \%$ under exposure to $0.2 \%$ bile salts after $24 \mathrm{~h}$ at $37^{\circ} \mathrm{C}$
(Sieladie et al., 2011). Antibiotic susceptibility of L1 and L2 revealed that selected bacterial strains were found susceptible to majority of the antibiotic discs used viz. Ampicillin (10 mcg), Gentamycin (10 mcg), Chloromphenicol (30 mcg), Ofloxacin $(10 \mathrm{mcg})$, Tetracycline $(25 \mathrm{mcg})$, Co-trimoxazol (30 mcg), Methicilin (30 mcg), Cefotaxime $(30 \mathrm{mcg})$ and Cephalothin (30 mcg), etc (Table 4), thus designating them free from any transferable resistance genes. In literature fifteen probiotic Lactobacilli upon testing for antibiotic susceptibility were found sensitive to penicillin, ampicillin, amoxicillin, erythromycin, tetracycline, chloramphenicol, and doxycycline while resistant to cotrimoxazole (Sieladie et al., 2011).

In order to complete list of the important probiotic attributes, hydrophobicity and auto aggregation properties of the selected bacterial strains were explored. The values (Fig. 4, Table 5) for their auto aggregation and hydrophobicity ranged upto $48.4 \%$ and 90 $\%$ respectively. In order to evaluate probiotic status, hydrophobicity and adherence properties of selected bacterial strains was performed and calculated value for the hydrophobicity was found to be $85.67,88.00$ and $76.33 \%$ for Lactobacillus paracasei, Lactobacillus plantarum and Lactobacillus brevis respectively (Jamaly et al., 2011).

Table.1 Preliminary screening of isolated potential probiotic lactic acid bacteria on the basis of their antagonistic pattern against test indicators by bit/disc method

\begin{tabular}{|c|c|c|c|c|c|c|c|c|c|c|c|c|c|}
\hline $\begin{array}{l}\text { Sr. } \\
\text { No. }\end{array}$ & $\begin{array}{l}\text { Name } \\
\text { of } \\
\text { isolate }\end{array}$ & Source & $\begin{array}{c}\text { L. } \\
\text { monocytogens } \\
(\mathrm{mm})\end{array}$ & $\begin{array}{c}C . \\
\text { perfringenes } \\
(\mathrm{mm})\end{array}$ & $\begin{array}{c}S . \\
\text { aureus } \\
(\mathrm{mm})\end{array}$ & $\begin{array}{c}\text { B. } \\
\text { cereus } \\
(\mathrm{mm})\end{array}$ & $\begin{array}{c}E . \\
\text { feacalis } \\
(\mathrm{mm})\end{array}$ & $\begin{array}{c}R . \\
\text { solani } \\
(\mathrm{mm})\end{array}$ & $\begin{array}{c}\text { A.niger } \\
(\mathrm{mm})\end{array}$ & $\begin{array}{l}\text { Rhizopus } \\
\text { (mm) }\end{array}$ & $\begin{array}{l}\text { Fusarium } \\
(\mathrm{mm})\end{array}$ & Mean & $\begin{array}{c}\text { Percent } \\
\text { Inhibition } \\
(\%)\end{array}$ \\
\hline 1. & B1 & $\begin{array}{l}\text { Chur } \\
\text { saag }\end{array}$ & - & 9.1 & 14.8 & - & - & 8.0 & - & - & - & 3.54 & 33.3 \\
\hline 2. & B2 & $\begin{array}{l}\text { Chur } \\
\text { saag }\end{array}$ & 12.4 & - & - & - & 9.5 & - & - & 3.0 & - & 2.76 & 33.3 \\
\hline 3. & $* \mathrm{~L} 1$ & Luske & 10.0 & 14.0 & 10.1 & 21.0 & 20.0 & 10.0 & 14.0 & 13.0 & - & 12.4 & 88.9 \\
\hline 4. & S6 & Siddu & 15.0 & - & 16.0 & - & - & - & 6.0 & - & - & 4.11 & 33.3 \\
\hline 5. & $* \mathrm{~L} 2$ & Luske & 16.0 & 19.0 & 15.0 & 30.0 & 30.0 & 16.0 & - & 12.5 & - & 15.38 & 77.8 \\
\hline 6. & $\mathrm{~T} 2$ & Siddu & - & - & - & 10.0 & - & - & 9.0 & - & - & 2.11 & 22.2 \\
\hline
\end{tabular}


Table.2 Identification of finally screened potential probiotic isolates

\begin{tabular}{|c|c|c|c|c|c|}
\hline $\begin{array}{l}\text { Name of } \\
\text { isolate }\end{array}$ & Source & $\begin{array}{l}\text { Closest homologue } \\
\text { (organism) }\end{array}$ & $\begin{array}{l}\text { Identity } \\
(\%)\end{array}$ & $\begin{array}{c}\text { 16S rRNA } \\
\text { identification }\end{array}$ & Accession No. \\
\hline $\mathrm{L} 1$ & Luske & $\begin{array}{c}\text { Pediococcus } \\
\text { acidilactici }\end{array}$ & $99 \%$ & $\begin{array}{c}\text { Pediococcus } \\
\text { acidilactici }\end{array}$ & KM251713 \\
\hline L2 & Luske & $\begin{array}{c}\text { Lactobacillus } \\
\text { plantarum }\end{array}$ & $99 \%$ & $\begin{array}{c}\text { Lactobacillus } \\
\text { plantarum }\end{array}$ & KM251714 \\
\hline
\end{tabular}

Table.3 Evaluation of screened potential probiotic isolates for acidity tolerance

a) Pediococcus acidilactici $\mathrm{L} 1$

$\mathrm{pH}$

\begin{tabular}{ccc} 
& $\begin{array}{c}\mathbf{0} \\
\mathbf{c f u} / \mathbf{m} \mathbf{l}^{*}\end{array}$ & $\begin{array}{c}\text { cfu/ml* } \\
(\mathbf{L o g})\end{array}$ \\
$\mathbf{1}$ & 9.113 & 6.903 \\
$\mathbf{2}$ & 9.556 & 7.491 \\
$\mathbf{3}$ & 10.276 & 8.193 \\
$\mathbf{6 . 5}$ & 10.705 & 10.704 \\
$\mathbf{C D}$ & & \\
\hline
\end{tabular}

30

survival
$(\%)$
75.7
78.4
79.7
100

Incubation time (min)

60

\begin{tabular}{cc} 
cfu/ml* & survival \\
$(\mathbf{L o g})$ & $(\%)$ \\
0.000 & 0.0 \\
7.431 & 77.8 \\
8.146 & 79.3 \\
10.707 & 100 \\
0.003 & \\
\hline
\end{tabular}

90

$\begin{array}{cc}\text { cfu/ml* } & \begin{array}{cc}\text { survival } \\ (\mathbf{L o g})\end{array} \\ 0.000 & (\%) \\ 5.255 & 0.0 \\ 7.107 & 54.9 \\ 10.706 & 69.2 \\ & 100\end{array}$

*Log cfu/ml: Mean of results from three separate experiments

b) Lactobacillus plantarum L2

$\mathrm{pH}$

$\begin{array}{cc} & \begin{array}{c}\text { 0 } \\ \text { cfu/ml* } \\ (\mathbf{L o g})\end{array} \\ & 9.033 \\ \mathbf{1} & 9.681 \\ \mathbf{2} & 9.303 \\ \mathbf{3} & 9.599 \\ \mathbf{6 . 5} & \end{array}$

cfu/ml*
(Log)
6.903
7.544
8.262
9.598

30

**survival
$(\%)$
76.4
77.9
88.8
100

Incubation time (min)

60

$\begin{array}{cc}\text { cfu/ml } * & * * \text { survival } \\ (\mathbf{L o g}) & (\%) \\ 0.000 & 0.0 \\ 7.505 & 77.5 \\ 8.212 & 88.3 \\ 9.597 & 100 \\ 0.024 & \end{array}$

90

$\begin{array}{cc}\text { cfu/ml* } & \text { **survival } \\ (\mathbf{L o g}) & (\%) \\ 0.000 & 0.0 \\ 5.414 & 55.9 \\ 6.201 & 66.7 \\ 9.600 & 100\end{array}$

* Same as Table 3(a)

Table.4 Detection of antibiotic sensitivity for screened potential probiotic bacterial isolates

\begin{tabular}{|c|c|c|c|c|c|c|c|c|c|c|c|c|c|c|c|c|c|c|}
\hline $\begin{array}{l}\dot{0} \\
\dot{z} \\
\dot{n}\end{array}$ & 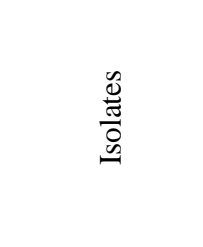 & $\frac{\Xi}{\Xi}$ & 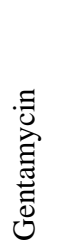 & 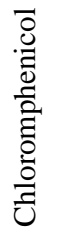 & 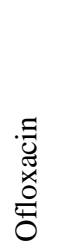 & 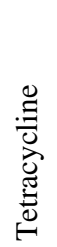 & 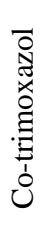 & 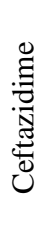 & 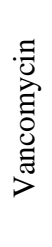 & 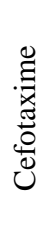 & 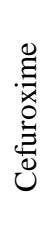 & 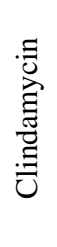 & 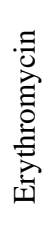 & 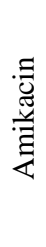 & 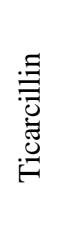 & 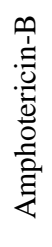 & 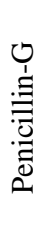 & 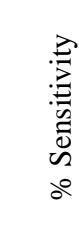 \\
\hline 1. & $\begin{array}{l}\text { Pediococcus } \\
\text { acidilactici } \mathrm{L} 1\end{array}$ & S & $S$ & $S$ & $S$ & $\mathrm{~S}$ & $\mathrm{R}$ & $\mathrm{R}$ & S & $S$ & $\mathrm{R}$ & $S$ & S & $\mathrm{S}$ & $S$ & $S$ & $\mathrm{R}$ & 75 \\
\hline 2. & $\begin{array}{l}\text { Lactobacillus } \\
\text { plantarum L2 }\end{array}$ & $S$ & $\mathrm{~S}$ & S & $S$ & S & S & $\mathrm{R}$ & S & $S$ & $\mathrm{~S}$ & $\mathrm{R}$ & $S$ & $\mathrm{R}$ & $S$ & S & $\mathrm{S}$ & 81.25 \\
\hline
\end{tabular}


Table.5 Expression of adhesion to different hydrocarbons by screened potential probiotic Bacterial isolates

\begin{tabular}{|c|c|c|c|c|c|c|c|c|}
\hline \multirow{2}{*}{$\begin{array}{l}\text { Sr. } \\
\text { No }\end{array}$} & \multirow[t]{2}{*}{ Isolate } & \multicolumn{2}{|r|}{ Xylene } & \multicolumn{2}{|c|}{ Chloroform } & \multicolumn{2}{|c|}{ Ethyl acetate } & \multirow{2}{*}{$\begin{array}{c}\text { Indication } \\
\text { a }\end{array}$} \\
\hline & & $\mathrm{OD}_{600}$ & $\begin{array}{c}\% \\
\text { Hydrophobicity }\end{array}$ & $\mathrm{OD}_{600}$ & $\begin{array}{c}\% \\
\text { Hydrophobicity }\end{array}$ & $\mathrm{OD}_{600}$ & $\begin{array}{c}\% \\
\text { Hydrophobicity }\end{array}$ & \\
\hline 1. & $\begin{array}{l}\text { Pediococcusacidilactici } \\
\text { L1 }\end{array}$ & 0.15 & 70 & 0.19 & 62 & 0.35 & 30 & Strong \\
\hline 2. & $\begin{array}{l}\text { Lactobacillus plantarum } \\
\text { L2 }\end{array}$ & 0.05 & 90 & 0.07 & 86 & 0.34 & 32 & Strong \\
\hline
\end{tabular}

Table.6 Assessment of cumulative score of screened potential probiotic isolates

\begin{tabular}{|c|c|c|c|}
\hline \multirow[t]{2}{*}{ Probiotic characters } & \multirow[t]{2}{*}{ Indication } & \multicolumn{2}{|c|}{ Score } \\
\hline & & L1 & L2 \\
\hline Acidity tolerance & $\begin{array}{l}\text { Resistant }=1 \\
\text { Sensitive }=0\end{array}$ & 1 & 1 \\
\hline Bile salt tolerance & $\begin{array}{l}\text { Resistant }=1 \\
\text { Sensitive }=0\end{array}$ & 1 & 1 \\
\hline $\begin{array}{l}\text { Autoaggregation } \\
\text { capacity }\end{array}$ & $\begin{array}{c}\text { Positive }=1 \\
\text { Negative }=0\end{array}$ & 1 & 1 \\
\hline Hydrophobic & (Xylene/Toluene) $>40 \%$ & 1 & 1 \\
\hline Capacity & $\begin{array}{c}\text { Strong }=1 \\
(\text { Xylene/Toluene })>20 \% \\
\text { Moderate }=0.5 \\
(\text { Xylene/Toluene })<20 \% \\
\text { Low }=0\end{array}$ & & \\
\hline Antagonistic activity & $\begin{array}{c}5-10=0.25 \\
10-15=0.50 \\
15-20=0.75 \\
>20=1\end{array}$ & 0.50 & 1 \\
\hline $\begin{array}{l}\text { Antibiotic } \\
\text { sensitivity }\end{array}$ & $\begin{aligned} \text { Antibiotic sensitive } & =1 \\
\text { Antibiotic resistant } & =0\end{aligned}$ & 1 & 1 \\
\hline$* *$ Probi & $\begin{array}{l}\text { Total } \\
\text { ic Potential }(\%)\end{array}$ & $\begin{array}{l}5.50 / 6.0 \\
91.7\end{array}$ & $\begin{array}{c}6.0 / 6.0 \\
100\end{array}$ \\
\hline
\end{tabular}

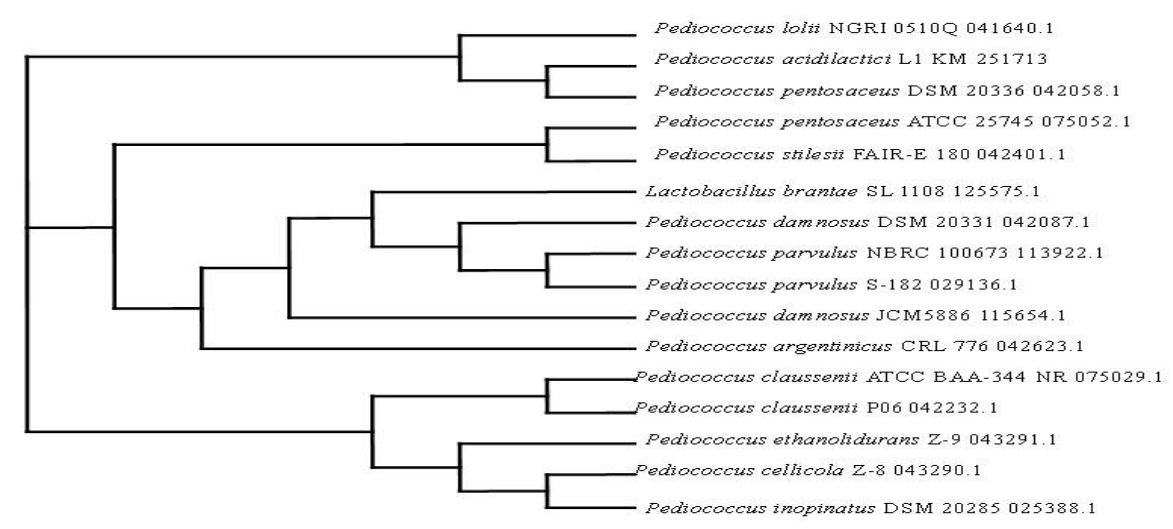

Fig 1. Phylogenetic tree of $P$ achihactici $L 1$ 
Fig.2 Phylogenetic tree of L. plantarum L2

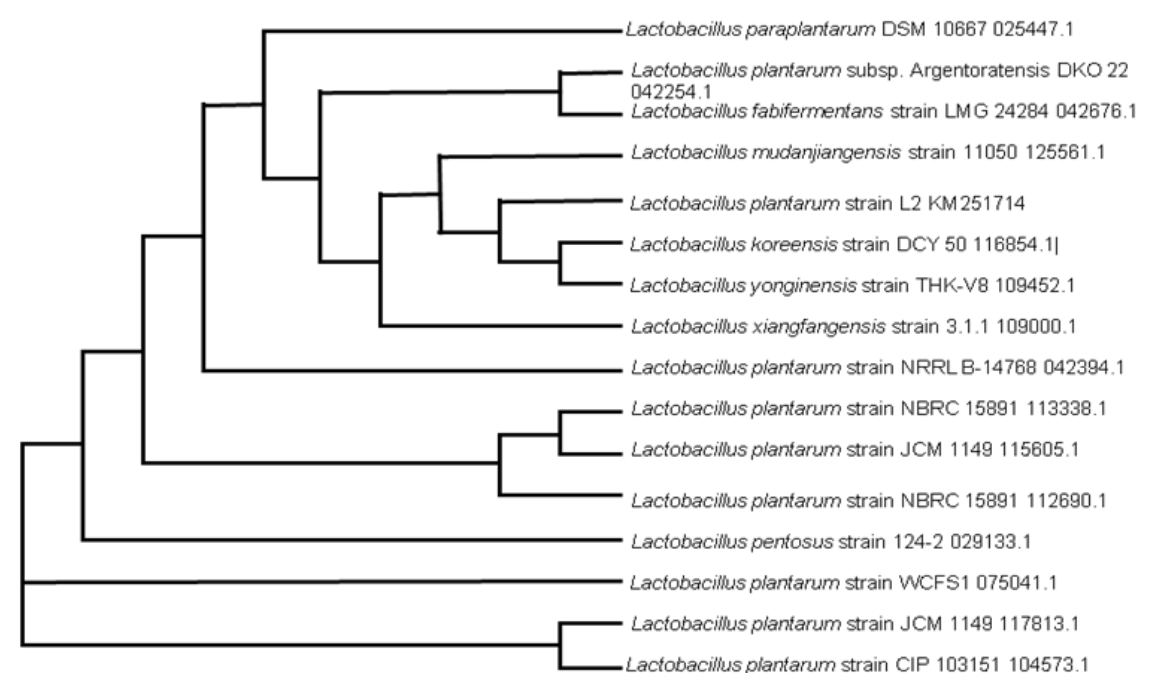

Fig.3 Percent survival of isolated potential probiotic lactic acid bacteria in the Presence of bile salt

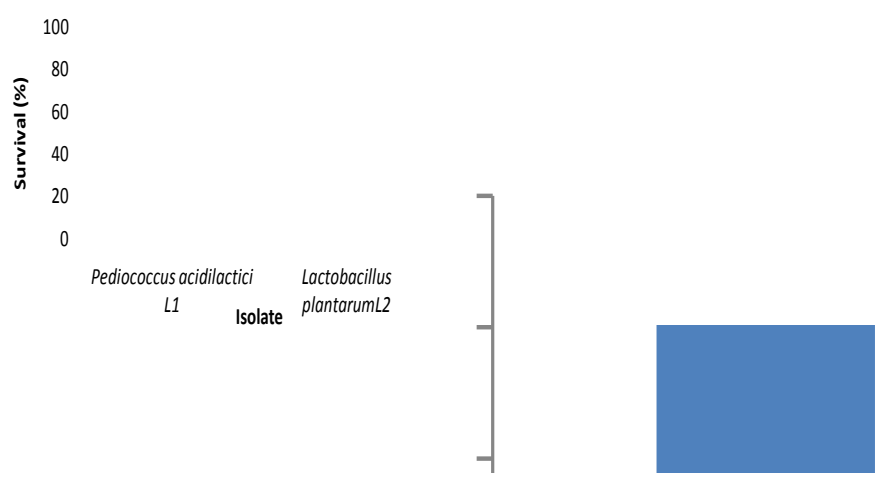

Fig.4 Comparisons of autoaggregability of screened potential probiotic bacterial isolates

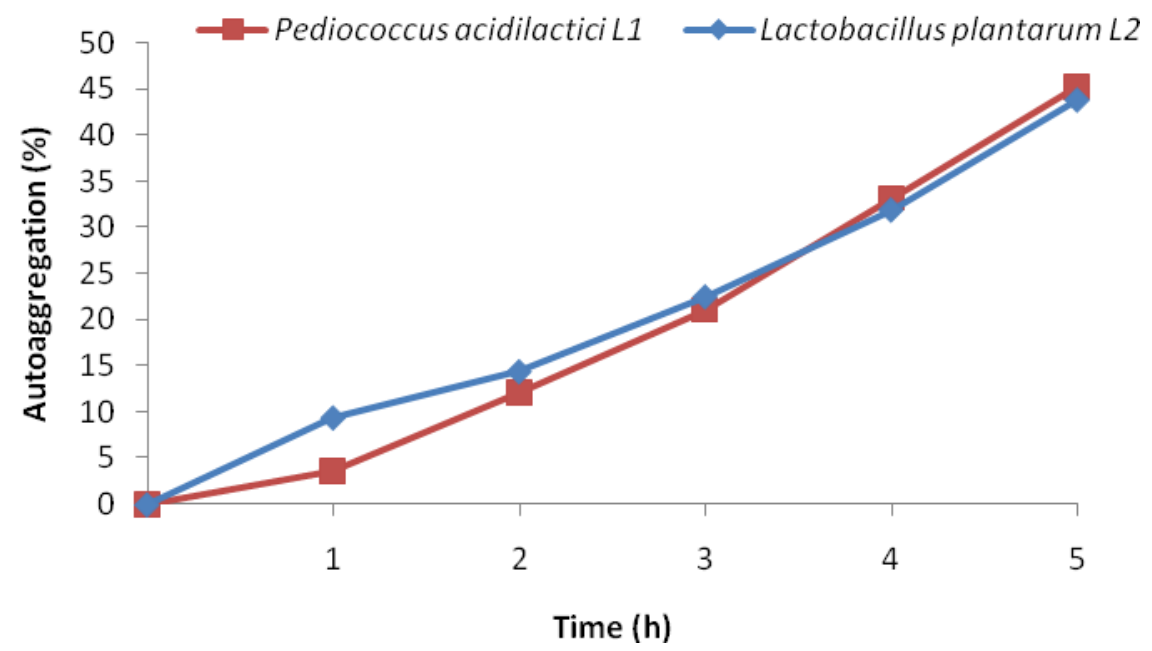




\section{Plate.1 Morphology of potential probiotic isolates}

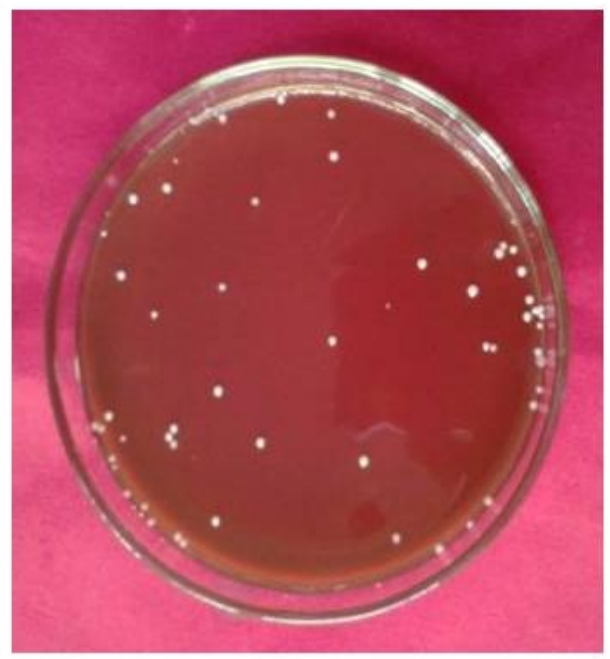

$\mathbf{L 1}$

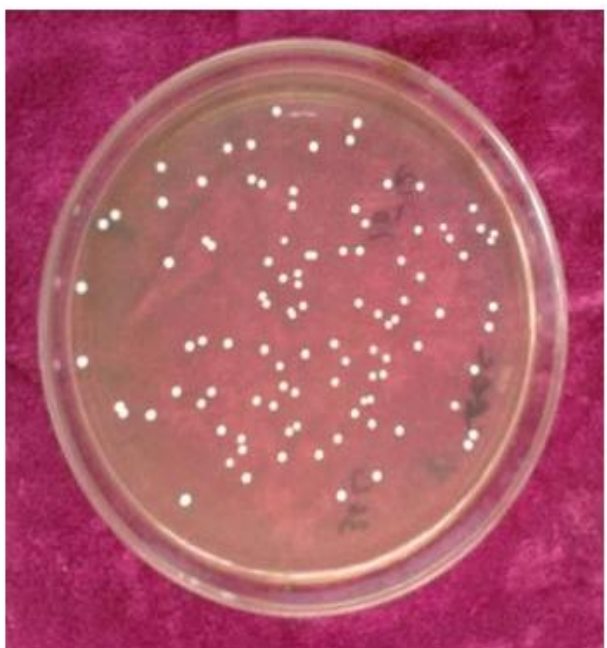

$\mathbf{L 2}$

Plate.2 Inter compatibility of screened potential probiotic bacterial isolates

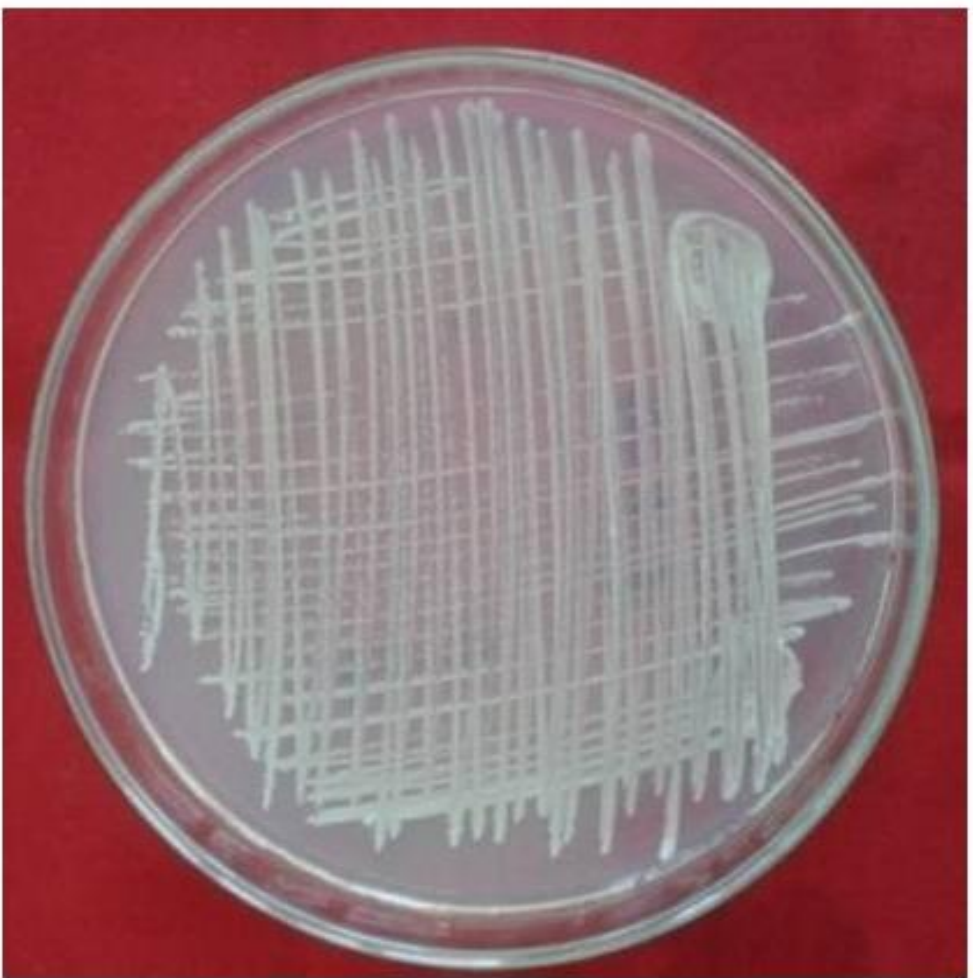

Pediococcus acidilectici L1 and Lactobecillus plenterum L2 


\section{Inter compatibility testing}

In order to formulate probiotic consortia, compatibility of screened two probiotic potential bacterial isolates was determined by cross streak method. Where two screened probiotic isolates were cross streaked against each other on prepoured MRS medium plates followed by incubation. It was observed that compatibility between both the strains was maximum for each other. Both the strains showed compatibility of $100 \%$ with their other counterparts as shown in Plate 2.

\section{Cumulative probiotic potential}

The sum of score of bile tolerance, acid tolerance, auto aggregation capacity, hydrophobic capacity, antibiotic sensitivity and antimicrobial activity marked as cumulative probiotic potential for Pediococcus acidilactici L1and Lactobacillus plantarum L2 was adjudged very high i.e. 91.7 and 100 respectively as given in table 6 . Thus, the screened probiotic potential bacterial isolates in the present study were qualified as robust probiotic strains and had been recommended to be used as commercial probiotics.

\section{Justification of the study}

Probiotics are generally sensitive under too many environmental stresses such as acidity, oxygen and heat. As probiotics are already given the status of GRAS (Generally Recognised as Safe), they are proved to be safe and effective for human consumption. But before a probiotic can benefit health of human being it must fulfill certain criteria related to the stability and safety. So, in the present study an effort has been made to assessed probiotic attributes of two selected strains Pediococcus acidilactici L1 and Lactobacillus plantarum L2. The encouraged results showed great potential of these strains to be used as probiotics and the strains can be helpful in the intestinal health of humans and animals.

Results obtained in this study showed great potential of the two lactic acid bacterial strains viz. Pediococcus acidilactici L1 and Lactobacillus plantarum L2. These isolates have very enhanced survival rate under the adverse gastric conditions of low $\mathrm{pH}$ and presence of certain amount of bile salts. They also have very good adhesion capacity for gastrointestinal tract. These strains also fulfilled the positive trait of sensitivity against most of the antibiotics used, as it is mandatory that the probiotics should be sensitive against majority of the antibiotics because the probability of transfer of resistant genes. So, it is clear from the study that these two strains of lactic acid bacteria can be beneficial for good digestibility and also in preparation of health beneficiary probiotic products.

\section{References}

Askari, G. A., Kahouadji, A., Khedid, K., Charof, R., and Mennane, Z. 2012. Screenings of lactic acid bacteria isolated from dried fruits and study of their antibacterial activity. Middle-East Journal of Scientific Research. 11(2), 209-215.

Barefoot, S. F., and Klanhammer, T. R. 1983. Detection and activity of lactacin $\mathrm{B}$, a bacteriocin produced by Lactobacillus acidophilus. Applied and Environmental Microbiology. 45(6), 1808-1815.

Dora, I. A. P., and Glenn, R. G. 2002. Cholesterol assimilation by lactic acid bacteria and bifidobacteria isolated from the human gut. Applied Environmental Microbiology. 68, 46894693.

FAO/WHO. 2006. Probiotic in foods, Health and nutritional properties and guidelines 
for evaluation In: FAO Food and Nutrition. pp. 85.

Gotcheva, V., Hristozova, E., Hristozova, T., Guo, M., Roshkova, Z., and Angelov, A. 2002. Assessment of potential probiotic properties of lactic acid bacteria and yeast strains. Food Biotechnology. 16, 211-225.

Jamaly, N., Benjouad, A., and Bouksaim, M. 2011. Probiotic potential of lactobacillus strains isolated from known popular traditional Moroccan dairy products. British Microbiology Research Journal. 1(4), 79-94.

Kos, B., Suskovic, J., Vukovic, S., Simpraga, M., Frece, J., and Matosic, S. 2003. Adhesion and aggregation ability of probiotic strain Lactobacillus acidophilus M92. Journal of Applied Microbiology. 94, 981-987.

Mishra, V., and Prasad, D. 2005. Application of in vitro methods for selection of Lactobacillus casei strains as potential probiotics. International Journal of Food Microbiology. 103, 109-115.

Pundir, R. K., Rana, S., Kashyap, N., and Kaur, A. 2013. Probiotic potential of lactic acid bacteria isolated from food samples: an in vitro study. Journal of
Applied Pharmaceutical Science 3(3), 85-93.

Rodriguez, R. L., and Tait, R. T. 1983. Recombinant DNA techniques, an introduction, Adisson Wesley, London, pp. 18- 236.

Shigwedha, N., Zhang, L., Sichel, L., Jia, L., Gong, P., Liu, W., Wang, S., Zhang, S., Han, X., and Gao, W. 2014. More than a few LAB alleviate common allergies: Impact of paraprobiotics in comparison to probiotical live cells. Journal of Biosciences and Medicines. 2, 56-64.

Sieladie, D. V., Zambou, N. F., Kaktcham, P. M., Cresci, A., and Fonteh, F. 2011. Probiotic properties of lactobacilli strains isolated from raw cow milk on the western highlands of Cameroon. Innovative Romanian Food Biotechnology. 9, 12-28.

Tambekar, D. H., and Bhutada, S. A. 2010. An evaluation of probiotic potential of Lactobacillus sp. from milk of domestic animals and commercial available probiotic preparations in prevention of enteric bacterial infections. Recent Research in Science and Technology. 2(10), 82-88.

\section{How to cite this article:}

Ranjana Sharma and Nivedita Sharma. 2017. Assessment of Probiotic Attributes of Food Grade Lactic Acid Bacteria Isolated from a Novel Traditional Fermented Product- Luske of Northern Himalayas. Int.J.Curr.Microbiol.App.Sci. 6(7): 2481-2490.

doi: https://doi.org/10.20546/ijcmas.2017.607.352 